\title{
Investigation of the effect of a noise barrier on a railway track in the Kysuce region
}

\author{
Alžbeta Pultznerová ${ }^{1, *}$ and Juraj Grenčík ${ }^{2}$ \\ ${ }^{1}$ Žilinská univerzita v Žiline, SvF, KZSTH, Univerzitná 8215/1, 01026 Žilina, Slovak Republic \\ 2ZŽilinská univerzita v Žiline, SjF, KDMT, Univerzitná 8215/1, 01026 Žilina, Slovak Republic
}

\begin{abstract}
Purpose of the noise barriers is to create an acoustically sufficient impermeable obstacle located on the sound wave propagation path, thereby creating a shadow of the sound pressure level behind the barrier. The paper is focused on the analysis of measured noise values at specific selected points of the railway track in the region of Kysuce without noise barrier and on the determination of noise barrier efficiency. The observed values are compared with the permissible noise values specified by the Slovak legislation
\end{abstract}

\section{Introduction}

The railway transport is generally considered to be more environmental friendly when comparing to other modes of transport, especially in terms of air pollution because of smaller specific energy consumption and using electric traction. However, the railway noise as an important factor of the environment it is the second most dominant source of the environmental noise in Europe. According [1], in 2012 there were almost 7 million inhabitants exposed to noise levels exceeding $55 \mathrm{~dB} L_{d a y}$ considering just inhabitants in urbanised regions.

The railway line No 127 Žilina - Čadca was included to the international transit corridors in Slovakia as part of the pan-European corridor, but the sections of the corridor did not meet the criteria of modernized lines. The main objectives was thus to modernize the technical infrastructure of the railway line in order to achieve the parameters defined by the AGC and AGTC agreements and thus meet the criteria for the modernized line. This line has been modernized so far from Žilina to Krásno nad Kysucou railway station.

\section{Legal requirements on the noise limits produced by transport}

European Union defined its legal requirements (standards) for permissible noise limits for the road traffic already in 1970s. However, the noise standards for trains and railway transport came into force only in the beginning of the twenty-first century [2]. In 2007, Regulation 549/2007 of the Ministry of Health of the Slovak Republic, in which the permissible values of noise $L_{\text {Aeq,p }}$ for rail transport are reported. This decree is still valid and the permissible limits are presented in Table 1.

*Corresponding author: alzbeta.pultznerova@uniza.sk 
For the purposes of land-use planning and control, the noise levels are evaluated at the height of $1.5 \mathrm{~m} \pm 0.2 \mathrm{~m}$ above the ground surfaces outside the buildings or in a front of peripheral wall of a building, the noise are assessed at the distance of $1.5 \mathrm{~m} \pm 0.5 \mathrm{~m}$ from the wall and at $1.5 \mathrm{~m} \pm 0.2 \mathrm{~m}$ above the floor of the relevant floor level. The "Surroundings" means the area within $100 \mathrm{~m}$ distance from the axis of adjacent driving lane of road or from the axis of the adjacent railroad track [3].

Table 1. The permissible noise limits defining the parameters of environmental noise [3].

\begin{tabular}{|c|c|c|c|c|c|c|c|}
\hline \multirow{4}{*}{$\begin{array}{c}\text { Category } \\
\text { of the } \\
\text { area }\end{array}$} & \multirow{4}{*}{$\begin{array}{c}\text { Description of the protected } \\
\text { area or } \\
\text { outer space }\end{array}$} & \multirow{4}{*}{$\begin{array}{l}\text { The } \\
\text { reference } \\
\text { time } \\
\text { interval }\end{array}$} & \multicolumn{5}{|c|}{ Permissible noise values $(\mathrm{dB}) \mathrm{A}$} \\
\hline & & & \multirow{3}{*}{\begin{tabular}{|c} 
Land $^{\text {a) }}$ \\
and \\
water \\
transport \\
b)c $)$ \\
$L_{A e a n}$
\end{tabular}} & \multicolumn{3}{|c|}{ Traffic noise } & \multirow{3}{*}{$\begin{array}{c}\text { Noise } \\
\text { from } \\
\text { other } \\
\text { sources } \\
L_{\text {Aeq, } p}\end{array}$} \\
\hline & & & & & Air tra & insport & \\
\hline & & & & $\begin{array}{c}\underset{c)}{\operatorname{transport}} \\
L_{\text {Aeq, } p}\end{array}$ & $L_{A e q, p}$ & $L_{\text {Amax, } p}$ & \\
\hline \multirow[b]{2}{*}{ I. } & Territory with special protection & day & 45 & 45 & 50 & - & 45 \\
\hline & $\begin{array}{l}\text { against noise (e.g. spa towns, spa } \\
\text { and wellness resorts) }\end{array}$ & evening & $\begin{array}{l}45 \\
40\end{array}$ & $\begin{array}{l}45 \\
40\end{array}$ & 50 & - & 45 \\
\hline 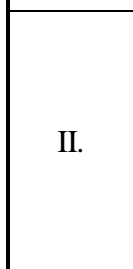 & $\begin{array}{l}\text { Space in front of the windows of } \\
\text { habitable rooms of the block of } \\
\text { flats and residential houses, the } \\
\text { space in front of windows } \\
\text { protected rooms of school } \\
\text { buildings, health care facilities } \\
\text { and other protected objects, d) } \\
\text { recreation area. }\end{array}$ & $\begin{array}{l}\text { day } \\
\text { evening } \\
\text { night }\end{array}$ & $\begin{array}{l}50 \\
50 \\
45\end{array}$ & $\begin{array}{l}50 \\
50 \\
45\end{array}$ & $\begin{array}{l}55 \\
55 \\
45\end{array}$ & $\begin{array}{l}- \\
- \\
65\end{array}$ & $\begin{array}{l}50 \\
50 \\
45\end{array}$ \\
\hline III. & $\begin{array}{l}\text { Territory as in the category II } \\
\text { around the highways, roads I and } \\
\text { II. classes, local roads with public } \\
\text { transport, railways and airports, } \\
\text { city centres. }\end{array}$ & $\begin{array}{l}\text { day } \\
\text { evening } \\
\text { night }\end{array}$ & $\begin{array}{l}60 \\
60 \\
50\end{array}$ & $\begin{array}{l}60 \\
60 \\
55\end{array}$ & $\begin{array}{l}60 \\
60 \\
50\end{array}$ & $\begin{array}{l}- \\
- \\
75\end{array}$ & $\begin{array}{l}50 \\
50 \\
45\end{array}$ \\
\hline IV. & $\begin{array}{l}\text { Territory without housing } \\
\text { function and without protected } \\
\text { outdoor space, production zones, } \\
\text { industrial parks, resorts plants }\end{array}$ & $\begin{array}{l}\text { day } \\
\text { evening } \\
\text { night }\end{array}$ & $\begin{array}{l}70 \\
70 \\
70\end{array}$ & $\begin{array}{l}70 \\
70 \\
70\end{array}$ & $\begin{array}{l}70 \\
70 \\
70\end{array}$ & $\begin{array}{l}- \\
- \\
95\end{array}$ & $\begin{array}{l}70 \\
70 \\
70\end{array}$ \\
\hline
\end{tabular}

\section{Noise study carried out in the Kysuce Region}

At first a noise study and in-situ measurements were carried out for a non-modernized line. The values obtained were used for evaluation of compliance or exceeding the permissible values according to the valid legislation. The measured points were chosen in the residential area in the surroundings of the assessed railway line No 127 of the Slovak railways in the village of Horelica. No modernization has been carried out on this railway line.

\subsection{Evaluation of the noise measurements}

To evaluate the assessed values for comparison with the limit value defined by the current legislation, the equivalent noise pressure level A - weighted sound pressure level is used.

Equivalent A - weighted sound pressure level of the continuous sound $L_{\text {Aeq, }}$ - timeaveraged mean sound pressure level A level, which is used to describe the sound with varying levels of sound. It is calculated as the sound pressure that is energetically equivalent to long-term effects of intermittent noise or noise with varying sound level [4]. 
The sound pressure level was calculated by the formula 1:

$$
L_{p A e q, T}=10 \cdot \log \left(\frac{1}{T} \cdot \int_{0}^{T} \frac{p_{A}^{2}(t)}{p_{0}^{2}} \mathrm{~d} t\right)(\mathrm{dB}) \mathrm{A}
$$

where:

$T$ - duration of sound measurement, (s),

$p_{0}$ - sound pressure reference value, $\left(2 \cdot 10^{-5} \mathrm{~Pa}\right)$,

$p_{A(t)}$ - instantaneous acoustic pressure of the sound signal, $(\mathrm{Pa})$.

The assessed measured value $L_{R, A e q, n}$ is the value $L_{p A e q, T}$ increased by uncertainty of measurement $U$.

Uncertainty of measurement and sound prediction was determined according to the Instruction No: NRÚ / 3116/2005 dated 2 May, 2005. Classification of the measured noise, depending on the frequency spectrum and its directional properties, shows the resulting expanded measurement uncertainty $U=1.8 \mathrm{~dB}$ [5].

From the particular hourly measurements of $L_{A e q, 1 h}$, noise events, which were not caused by railway operation, were "cut out". The particular hourly noise levels were energetically summarised by the formula [6]:

$$
L_{\text {Aeq, } p}=10 \cdot \log \left(\frac{1}{T} \sum_{j=1}^{8} 10^{0.1 L_{\text {Aeq, } j}}\right) \quad(\mathrm{dB}) \mathrm{A}
$$

where:

$L_{\text {Aeq, }} \quad-\quad$ evaluated equivalent noise pressure level (dB)A;

$L_{A e q, j} \quad$ equivalent noise pressure level measured in one hour intervals (dB)A;

$j \quad-\quad$ number of equivalent noise pressure levels measured during night time;

$T \quad-\quad$ measurement duration, in our case it was 8 hour (from 22:00 to 6:00). (h)

\subsection{Assessment of the noise study in the Kysuce region}

Measurements and the assessment of the equivalent noise pressure levels were carried out during the night time on the railway line No 127 in various places in the village of Horelica.

Measuring point positions:

M1 $-2 \mathrm{~m}$ in front of the window of residential room on $7^{\text {th }}$ floor of Home of social services and facilities for seniors No 107, Horelica, approximately $133 \mathrm{~m}$ from railway track No 127 ,

M2 $-2 \mathrm{~m}$ in front of the window of residential room on $2^{\text {nd }}$ floor of the house No 463 , Horelica, approximately $31 \mathrm{~m}$ from railway track No 127 and $10 \mathrm{~m}$ from the road.

M3 $-2 \mathrm{~m}$ in front of the window of residential room on $2^{\text {nd }}$ floor of the house No 390 , Horelica, approximately $85 \mathrm{~m}$ from railway track No 127 and approximately $28 \mathrm{~m}$ from the road I/11.

In Fig. 1, the positions of the microphone and the railway track at measuring point M2 are shown. 


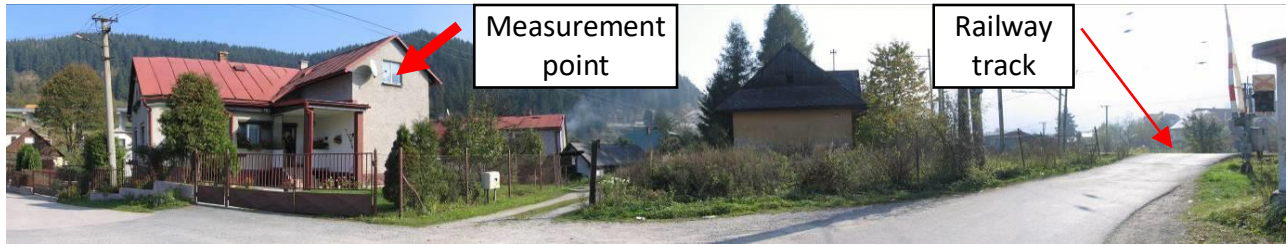

Fig. 1. Example of measurement at measuring point M2 in the village of Horelica [7].

The digital orthophotomap of the area of interest and the location of the measurement points is shown in Fig. 2.

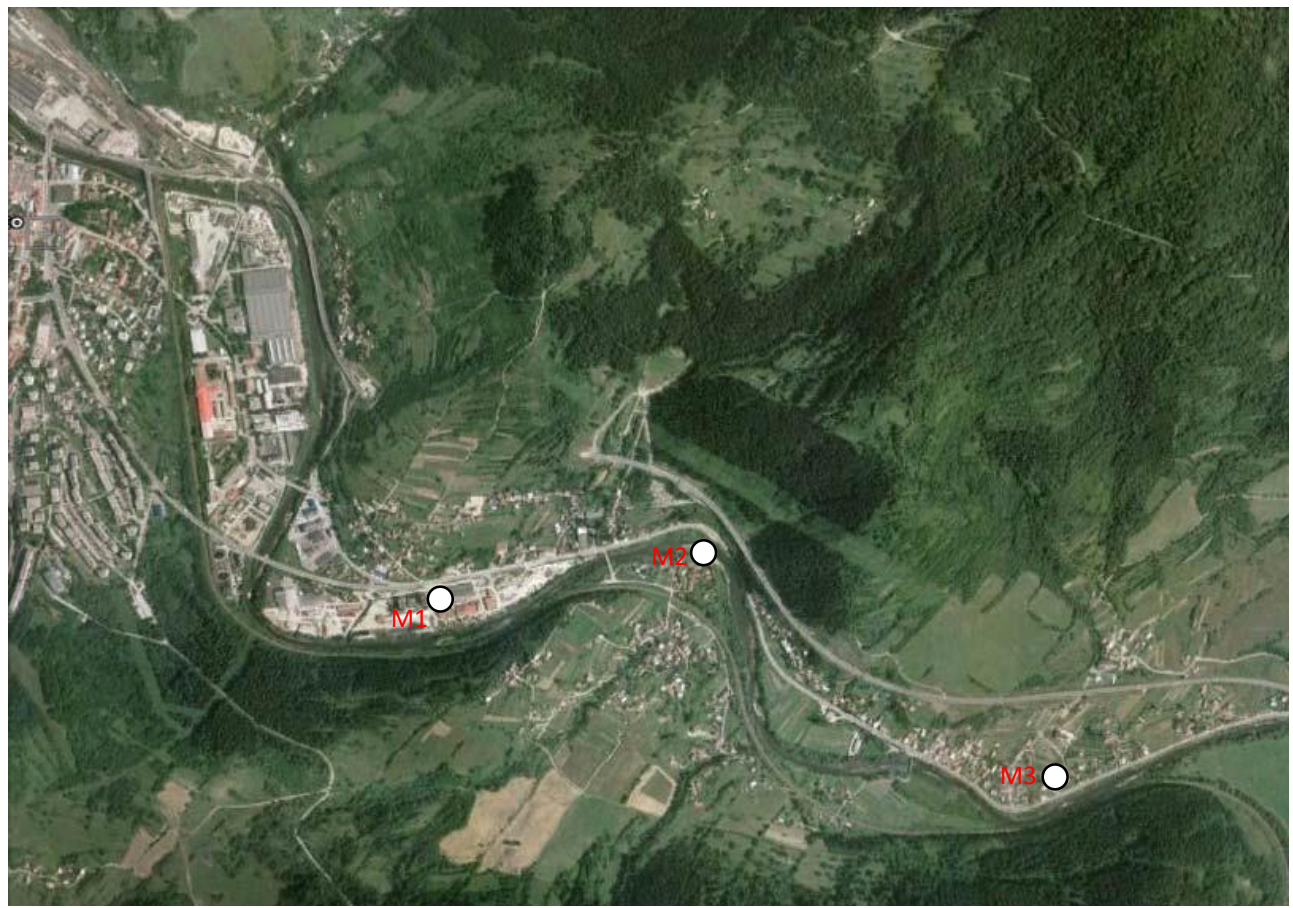

Fig. 2. Location of the measurement points in the village of Horelica.

Measurements were carried out during 13 - 14 November 2010 at night time from 22:00 to 6:00, when the permissible noise limits given by the standard are the most strict, 55 and 45 $\mathrm{dB}(\mathrm{A})$ respectively.

As it can be seen from the measurement example, the sound events that did not belong to the noise from the railway operation had to be filtered out and this gave the specific total sound resulting caused by the operation on the railway line No 127 .

The measured and calculated values are given in Table 2 . 
Table 2. Measured hourly A equivalent sound pressure levels at measuring points [own research].

\begin{tabular}{|c|c|c|c|c|c|c|c|c|c|c|}
\hline \multirow{3}{*}{$\begin{array}{c}\text { Measuring } \\
\text { points }\end{array}$} & \multicolumn{8}{|c|}{ Time (h) } & \multirow{3}{*}{$\begin{array}{c}\text { Total } \\
\text { resulting } \\
\text { sound } \\
L_{p A e q, 8 \mathrm{~h}} \\
(\mathrm{~dB}) \mathrm{A}\end{array}$} & \multirow{3}{*}{$\begin{array}{c}\text { Total } \\
\text { only from } \\
\text { the rail. } \\
\text { line } \\
L_{p A e q}, 8 \mathrm{~h} \\
(\mathrm{~dB}) \mathrm{A}\end{array}$} \\
\hline & $22-23$ & 23-00 & 00-01 & 01-02 & 02-03 & 03-04 & 04-05 & 05-06 & & \\
\hline & \multicolumn{8}{|c|}{$L_{p A e q}, 1 \mathrm{~h}(\mathrm{~dB}) \mathrm{A}$} & & \\
\hline M1 & 57.3 & 48.0 & 57.0 & 60.7 & 40.0 & 60.4 & 58.6 & 63.3 & 58.9 & 58.7 \\
\hline M2 & 65.5 & 63.2 & 63.0 & 68.2 & 72.3 & 69.0 & 68.1 & 72.1 & 68.9 & 68.8 \\
\hline M3 & 64.1 & 60.3 & 59.8 & 64.2 & 68.5 & 65.0 & 64.6 & 67.8 & 65.2 & 64.6 \\
\hline
\end{tabular}

The comparison of the assessed measured value $L_{R, A e q, n}$, which are increased by the measurement uncertainty from the measured value, with the permissible noise value (PV) is given in Table 3.

Table 3. Evaluation of the measured and the calculated values [own research].

\begin{tabular}{|c|c|c|c|c|c|c|}
\hline $\begin{array}{c}\text { Assessed point (altitude } \\
\text { from the ground/ } \\
\text { distance from the rail. } \\
\text { track) } \\
(\mathrm{m})\end{array}$ & $\begin{array}{c}\text { Land } \\
\text { category }\end{array}$ & $\begin{array}{c}\text { PV } \\
(\mathrm{dB}) \mathrm{A}\end{array}$ & $\begin{array}{c}\text { Measured } \\
\text { values } \\
(\mathrm{dB}) \mathrm{A}\end{array}$ & $\begin{array}{c}\text { Assessed } \\
\text { measured value } \\
L_{R, \text { Aeq, }} \\
(\mathrm{dB}) \mathrm{A}\end{array}$ & $\begin{array}{c}L_{R, \text { Aeq,n }} \\
\mathrm{PV} \\
(\mathrm{dB}) \mathrm{A}\end{array}$ \\
\hline $\mathrm{M} 1$ & $7 \mathrm{NP} / 133$ & II. & 45 & 58.7 & $60.5>45$ & 15.5 \\
\hline $\mathrm{M} 2$ & $2 \mathrm{NP} / 31$ & III. & 55 & 68.8 & $70.6>55$ & 15.6 \\
\hline $\mathrm{M} 3$ & $2 \mathrm{NP} / 85$ & III. & 55 & 64.6 & $66.4>55$ & 11.4 \\
\hline
\end{tabular}

\section{Measurement of equivalent noise level before and after noise barrier}

Measurements were realized on the modernized double-track railway line Žilina-Čadca No 127 near the village of Dunajov in order to determine the equivalent sound pressure values on the upgraded line and the effectiveness of the noise barrier.

The International Standard STN ISO 10847 specifies two methods for the determination of embedded attenuation of external noise barriers - direct and indirect method. It is recommended to use the direct measurement method. An alternative method is an indirect measurement method using levels measured at an equivalent site without a barrier [8]

The direct method is such that a measurement is made before and behind the structure of the noise barrier. This method has the disadvantage that the transport and structural characteristics of the railway track may have changed, so that the noise source is not the same due to the measurement offset time. In the indirect method, points equidistant from and with a noise barrier rail track has to be selected, taking into account the natural environmental conditions (terrain reflectance, terrain profile, free sound propagation without acoustic shadow or reflections from buildings) were the same.

The measurement was realized using the second method at two locations at the same time: behind the noise barrier (Fig. 3a) and at the same distance from the no-wall track 
(Fig. 3b) under the same environmental conditions. The microphones were at the distance of $151 \mathrm{~m}$ from each other and at the distance of $12 \mathrm{~m}$ from the track.

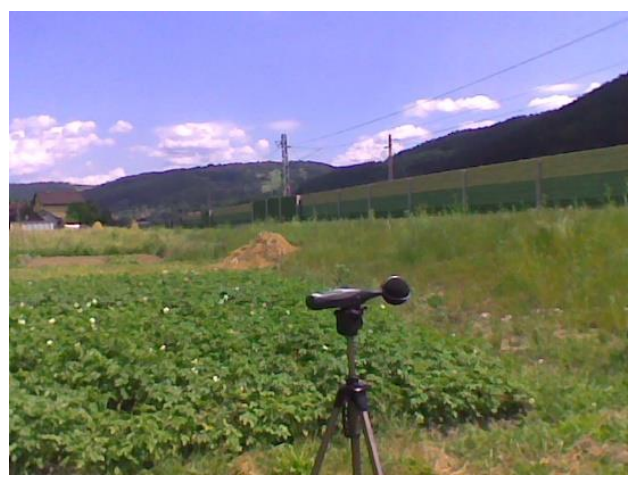

Fig. 3a. Location of the measurement microphone with noise barrier [9].

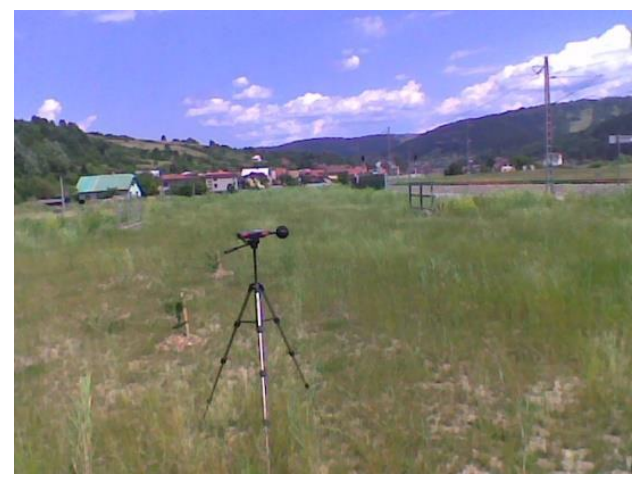

Fig. 3b. Location of the measurement microphone without noise barrier [9].

The hourly measurements were not realised, only the noise loads from individual passing trains were compared. The result of the measurements of the regional train (RT), express (Ex), freight train (FT) and locomotive train (LT) is in Table 4. Comparison of the maximum noise levels is shown in Fig. 4. An example of passing different types of trains is given in Table 5.

Table 4. Difference of noise loading of passing trains with and without noise barrier.

\begin{tabular}{|c|c|c|c|c|c|c|c|c|c|c|c|c|}
\hline Time & \multicolumn{9}{|c|}{ Train passage } & \multicolumn{4}{c|}{$\begin{array}{c}L_{A, \max } \\
(\mathrm{dB}) \mathrm{A}\end{array}$} & \multicolumn{3}{c|}{$L_{\text {Aeq }}(\mathrm{dB}) \mathrm{A}$} \\
\hline (h:min) & type & direc & loco & wag & track & $\begin{array}{c}\text { passage } \\
\text { time } \\
\text { (s) }\end{array}$ & $\begin{array}{c}\text { without } \\
\text { barrier }\end{array}$ & $\begin{array}{c}\text { with } \\
\text { barrier }\end{array}$ & difference & $\begin{array}{c}\text { without } \\
\text { barrier }\end{array}$ & $\begin{array}{c}\text { with } \\
\text { barrier }\end{array}$ & difference \\
\hline $9: 51$ & RT & CA & 1 & 4 & 2 & 11.3 & 84.0 & 72.9 & 11.1 & 78.9 & 66.3 & 12.6 \\
\hline $9: 55$ & Ex & ZA & 1 & 4 & 1 & 13.9 & 91.5 & 76.5 & 15.0 & 82.3 & 68.2 & 14.1 \\
\hline $10: 03$ & Ex & CA & 1 & 6 & 2 & 17.2 & 89.8 & 75.8 & 14.0 & 79.2 & 66.0 & 13.2 \\
\hline $10: 06$ & FT & ZA & 2 & 33 & 1 & 32.8 & 86.1 & 71.5 & 14.6 & 80.6 & 66.2 & 14.4 \\
\hline $10: 35$ & FT & CA & 2 & 33 & 2 & 38.2 & 84.2 & 72.1 & 12.1 & 80.6 & 68.5 & 12.1 \\
\hline $10: 42$ & RT & ZA & 1 & 5 & 1 & 16.2 & 85.6 & 68.8 & 16.8 & 78.2 & 63.4 & 14.8 \\
\hline $11: 26$ & FT & CA & 2 & 31 & 2 & 34.6 & 87.1 & 77.4 & 9.7 & 82.7 & 70.9 & 11.8 \\
\hline $11: 32$ & LT & CA & 1 & 0 & 2 & 5.0 & 76.9 & 62.7 & 14.2 & 71.7 & 58.6 & 13.1 \\
\hline $11: 40$ & FT & ZA & 1 & 32 & 1 & 41.0 & 92.9 & 77.1 & 15.8 & 87.0 & 71.9 & 15.1 \\
\hline $11: 52$ & RT & ZA & 1 & 5 & 2 & 17.9 & 85.5 & 70.8 & 14.7 & 77.1 & 63.3 & 13.8 \\
\hline $12: 01$ & Ex & CA & 1 & 4 & 2 & 15.9 & 90.0 & 75.4 & 14.6 & 81.6 & 68.0 & 13.6 \\
\hline $12: 03$ & FT & ZA & 2 & 33 & 1 & 45.2 & 88.6 & 75.0 & 13.6 & 84.6 & 71.1 & 13.5 \\
\hline $12: 16$ & Ex & ZA & 1 & 6 & 1 & 15.7 & 90.7 & 75.9 & 14.8 & 82.4 & 67.1 & 15.3 \\
\hline
\end{tabular}




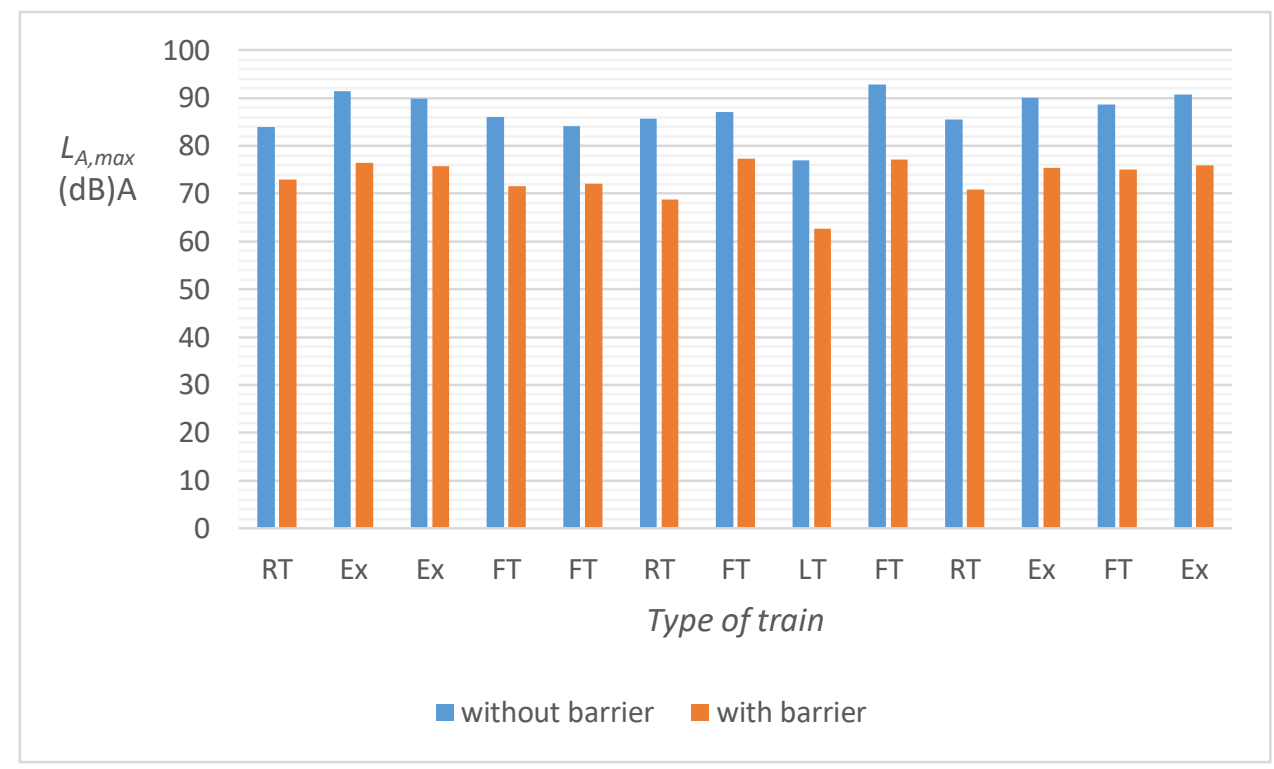

Fig. 4. Graphical representation of maximum noise levels with and without noise barrier [9].

Table 5. Effect of noise barrier of different types of trains.

\begin{tabular}{|c|c|c|c|}
\hline Type of train & without barrier & with barrier & difference \\
\hline RT & $L_{\text {Aeq }}=78.9(\mathrm{~dB}) \mathrm{A}$ & $L_{\text {Aeq }}=66.3(\mathrm{~dB}) \mathrm{A}$ & $12.6(\mathrm{~dB}) \mathrm{A}$ \\
\hline $\mathrm{Ex}$ & $L_{\text {Aeq }}=82.3(\mathrm{~dB}) \mathrm{A}$ & $L_{\text {Aeq }}=68.2(\mathrm{~dB}) \mathrm{A}$ & $14.1(\mathrm{~dB}) \mathrm{A}$ \\
\hline $\mathrm{FT}$ & $L_{A e q}=87.0(\mathrm{~dB}) \mathrm{A}$ & $L_{A e q}=71.9(\mathrm{~dB}) \mathrm{A}$ & $15.1(\mathrm{~dB}) \mathrm{A}$ \\
\hline
\end{tabular}

\section{Conclusions}

It is clear from the noise study that the permissible noise levels in the Kysuce region before the construction of noise barriers were exceeded by 11 to $15(\mathrm{~dB}) \mathrm{A}$ compared to the permissible noise levels at night. The noise barrier structure by the modernization of the railway line was therefore justified.

A comparison of the measured values of the equivalent sound pressure level $\mathrm{A}$ at a site without a noise barrier and at a site with the barrier indicates that the barrier has a noise attenuation level of railway traffic of 11-15 (dB)A. These values are equivalent noise values for the individual train passages. They cannot be compared with hourly equivalent values from the noise study. The hygienic measurements in the area should need to be carried out in order to compare whether the permissible noise values are satisfied. The positive acoustic effects of noise barriers have been confirmed by various measurements also in the past [10]. Besides overall sound pressure level, frequency dependence of noise propagation as well as the required noise attenuation parameters was evaluated, too.

This work was supported by the Grant National Agency VEGA of the Slovak Republic, project number 1/0006/20. 


\section{References}

1. European Environment Agency, Noise in Europe 2014, EEA report 10. Luxembourg (Publications Office of the European Union 2014)

2. Murphy and King: Environmental Noise Pollution: Noise Mapping, Public Health, and Policy (2014)

3. Decree of MH No. 549/2007 R.c. stating the details on the permissible levels of noise, infrasound and vibration and the requirements on objectification of noise, infrasound and vibration in the environment of $16^{\text {th }}$ August 2007 (2007)

4. STN EN ISO 3095 Railway applications. Acoustics. Measurement of noise emitted by railbound vehicles, (2006)

5. Professional guidance: NRÚ/3116/2005 (2005)

6. J. Veverka, V. Kozel, L. Ládyš, M. Liberko, J. Chybík, Building physics (in Slovak Stavebni fyzika), (University of Technology Brno, 1998)

7. Archive of the ZPS Club in vibroacoustics, s.r.o. (2010)

8. STN ISO 10847 Acoustics. In-situ determination of insertion loss of outdoor noise barriers of all type (in situ), (2000)

9. Archive of the Slovak Railways. Railway Research and Development Institute, Testing laboratory of RRDI (2011)

10. R. Toma, P. Zvolenský, Measurement of frequency dependence of train noise at noise barrier on the corridor railway line, proceedings of papers from XVI. International Acoustic Seminar, Kočovce, Maj 30 - 31, 2011, Bratislava, p. 101-102 